in particular we ought to be told in some detail about the controversies that have taken up so much of Eysenck's academic life, and also about the kind of man he is. On both these counts Gibson's book is a clear failure. He hardly deals with the controversies at all. Eysenck's own views are described reasonably well but the arguments about them, though sometimes mentioned, are never pursued, and again and again Gibson resorts to the excuse that the issues are too complex for his book. This is indeed an unfortunate contrast with the subject of his book who has never hesitated to introduce the layman to exactly the issues which Gibson so consistently avoids.

Thus one of the most obvious opportunities of a book like this - the chance to see how psychology has advanced with the help of lively debates seen through the life of one of its main controversialists - is almost totally lost. Worse still, at times the book's account of Eysenck's controversies is quite seriously misleading. For example, there is a chapter called the "Psychology of Politics" which deals with two very disparate topics. One is Eysenck's theory, published in the $1950 \mathrm{~s}$, of the personality types associated with various political views, and in particular his amusing claim that right- and left-wing extremists have much in common, a suggestion which did not endear him either to the left or to the right. The second is the debate about the question of the relative effects of heredity and environment which Eysenck formed so vigorously in the 1970s. As far as I can see, Gibson's only reason for putting these two issues together is his idea that one of the reasons for the violent hostility which greeted Eysenck's views about the importance of heredity was the vindictive rage felt by left-wing elements at the earlier suggestion that they were brothers under the skin of the Fascist foes. There may have been people as lunatic as this, but there were also some serious, well-argued objections which we are not given. We hear about the riots and the punches, but not about the debate.

Nor is the book much more helpful about Eysenck's own personality. It seems that over the years he fell out with many of his important colleagues, but the reasons why remain obscure. Eysenck is apparently shy: yet he has the habit of making outrageously immodest, public claims about his own abilities. Gibson has no explanation for this seeming paradox. Another issue which is left quite unsettled concerns Eysenck's attitude to other people. Gibson takes pains to show how kind Eysenck can be, and of ten the book adopts the style of a life of one of the saints as it ramblingly recounts this or that good deed by the professor. St Francis gave his cloak to a poor man: Eysenck took a whole day off to fetch a colleague's baby from hospital. But the book also relays some ungenerous comments made by Eysenck about and sometimes directly to other people. I simply do not know what to conclude, and yet the question is important because one of the major reasons for Eysenck's success has been his ability to keep a large number of people around him working with enthusiasm on his ideas. I should have liked to have known how he did it.

Gibson's book is interesting and often entertaining. But it gives us nothing like a proper assessment of Eysenck's formidable contribution to psychology over the past three decades.

P.E. Bryant is Watts Professor of Psychology at the University of Oxford.

\title{
Archaeology in retrospect and in prospect
}

\section{J. Desmond Clark}

$\overline{\text { A Short History of Archaeology. By Glyn }}$ Daniel. Pp.232. ISBN 0-500-05041-4. (Thames and Hudson: 1981.) £9.50, \$17.95. Antiquity and Man: Essays in Honour of Glyn Daniel. Edited by John D. Evans, Barry Cunliffe and Colin Renfrew. Pp.256. ISBN 0-500-05040-6. (Thames and Hudson: 1981.) £25.

IT IS probably true to say that no school of archaeology has done more in the decades immediately preceding and following the Second World War than has that at the University of Cambridge. There are the unique contributions of Grahame Clark to understanding Mesolithic and Neolithic economy; of Charles McBurney to Palaeolithic studies through his excavations in North Africa, Iran, Afghanistan and Britain; of David Clarke in revolutionizing theory and concepts in archaeology; and of Glyn Daniel through his special interest in and encyclopaedic knowledge of the history of archaeology and the study of megalithic monuments.

These were scholars unsurpassed in their fields and their experience, knowledge and teaching have been responsible for the training of an unrivalled nucleus of the leading archaeologists working in the Western world today. In part this stems from the alliance between archaeology and anthropology that has always been present at Cambridge and the success of archaeological interpretation and model building has come from the understanding of human behaviour provided by ethnographic studies, not infrequently now being undertaken by the archaeologists themselves. While archaeology derives much of its methodology from the natural and earth sciences, interpretation can only come from the insights of the anthropologist. When Professor Glyn Daniel retired this July after 8 years in the Disney Chair at Cambridge and 35 years on the faculty, an era in British archaeology drew to a close. A new group of scholars, often his own students, have taken up the challenge of the modern, conceptual approach to the discipline and are among the leading contributors to it.

There is no one who has made more of an impact than Professor Daniel on our understanding of the history of archaeology and the way that this has influenced current theory, and on the story of its emer- gence from the enveloping strait-jacket of the Book of Genesis to become the creative and exciting discipline it is today. To celebrate his general editorship and the appearance of the hundred th volume in the Ancient Peoples and Places series published by Thames and Hudson, he has produced $A$ Short History of Archaeology.

The volume is divided into five main chapters that cover the growth of archaeological method and theory from the beginnings, through the formative and then the developmental years between the wars, to that of the "new and not-so-new archaeology". This is a well-written, witty and enjoyable summary of the main conceptual, analytical and methodological advances in the field of prehistoric and historic archaeology as manifested by accounts of the increasing numbers of significant and often very exciting finds, the development of survey, excavation and recording techniques, and the awakening interest of the general public. In other words, it is an excellent history of mankind's ideas about his ancient past. This approach enables archaeologists to appreciate the value of the historical framework that has made possible the advances in field work, analysis and interpretation of the past two decades. By trying to understand the tenor of intellectual thought at a particular time we are better able to appreciate the major developments in archaeological theory and the reasoning that lies behind them.

Following the ordering of assemblages of artefacts in the Three Ages System, to that of the Stage or Age based on stratigraphic excavation and the concept of the "type fossil", archaeology has moved on to determining patterns of economic and social behaviour. The major concern with chronology and time-depth, which for so long occupied the earlier archaeologists, has only been removed since the availability of techniques such as radiocarbon, potassium-argon and the palaeomagnetic reversal chronology made possible by physicists, chemists and geologists since 1950. We are now, therefore, in a position to know, even if we cannot comprehend, the magnitude of the time involved in the story of our biological and cultural evolution.

A Short History of Archaeology is a synthesis not only of the record for 
Western Europe but sets out to cover most of the world where archaeologists have made significant contributions. Thus the history of archaeology in the Americas, Africa, the Middle and Far East, and Australasia is discussed, though more satisfactorily for some areas than for others, depending on the author's viewpoint. The dramatic discoveries of Layard, Sohliemann, Petrie, Howard Carter, Arthur Evans and a host of others help to show the way in which archaeology has advanced from an over-emphasis on artefact morphology and typologies to the attempt to learn about the behaviour and the individuals that lie behind the tools themselves. The contributions of the systematic excavators and recorders - Pitt Rivers, Petrie, Mortimer Wheeler - and of those who sought to understand the processes behind culture change like Gordon Childe and the ethnographers receive here the credit they deserve.

Only in the last section of the book on the "new archaeology" does one get the impression that the author is not really in sympathy with his subject. Even though there is not all that much which is new in the more theoretical frameworks and the problem-orientated archaeology of today, it is the emphasis on this problem-orientated approach, coupled with the great advances in technique and method such as "edge polish" studies, spatial analysis, taphonomy and experimental archaeology, that is bringing about such an important re-orientation in our attitudes.

One thing that stands out from Glyn Daniel's intensive search of the literature is the way in which the intellectual world becomes receptive to new hypotheses and new constructs only when it is ready to do so and, although others before may have made the same observations and drawn the same conclusions, unless the scientific world is waiting for them they are quickly forgotten. The manner in which preconceptions can retard true understanding of the evidence is well seen in the early interpretation of Neanderthal man and the ease with which the Piltdown hoax was perpetrated. Glyn Daniel has led the way in showing that archaeology can be of interest for the layman as for the specialist and his works have been the forerunners of those hautes vulgarisations - accounts of all those prehistoric discoveries and palaeoanthropological wranglings - that delight the public today.

An excellent, well-selected set of colour and black and white illustrations accompany the text and this will certainly be a standard introductory textbook for years to come.

Antiquity and Man is not the usual kind of Festschrift which, all too often - as Glyn Daniel himself has said - is "a cemetery of articles which ought to have been published elsewhere in more accessible form, or not at all'. The Prince of Wales, who took the archaeology Tripos Part I at Cambridge and was taught by
Glyn Daniel, contributes a foreword, and essays by some 28 leading authorities on archaeological topics and other matters make up the volume. The subjects treated are of direct interest to Glyn Daniel who has had a major involvement with and made a great impact on most of them. It is both a stock-taking of the state of archaeology in the continents today and a discussion of some of the leading theories that lie behind recent advances.

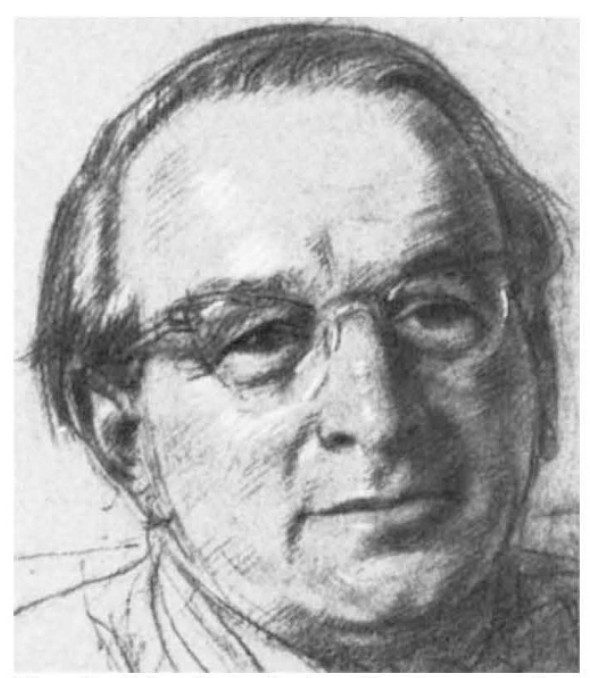

Glyn Daniel, who retired earlier this year after 35 years at Cambridge.

The book is divided into four unequal parts and comprises a valuable series of summary papers on a range of topics which show the extent of Professor Daniel's interest in and contributions to the discipline and also to Cambridge with its college dons and undergraduates. Space does not permit - and it would be invidious to single out - individual contributions from this outstanding text, but the first part contains several excellent summaries of the current state of archaeology in Europe and the Middle East, Africa, Australia and China. The reader is made to appreciate the contribution of the Cambridge School to the changing face of archaeology today in Third World countries - the need for the training of nationals to take over from the expatriates and the advantage for both of collaboration and the multidisciplinary, international team approach. Several authors make a plea for fieldwork and warn against its neglect in favour of the theoretical approach which is sometimes only too evident today. Fieldwork is indeed the life blood of archaeology, and models and hypotheses are worthless without the factual empirical data that come from meticulous field methods and objective analysis and interpretation.

Part II comprises nine essays on current theorics concerning the construction of megaliths found from the central Mediterranean to Britain and Scandinavia. Glyn Daniel played no small part in elucidating the mystery of their origins and significance. This section will be of especial interest to European archaeologists and shows well the shift in emphasis from the monuments themselves to attempting to learn about the populations that built them and the different economic and social organizations that gave rise to these ritual centres, often associated with communal burial. The diffusionist theory for the spread of megaliths has now been largely replaced by one of local, autochthonous development, while the radiocarbon and TL ages now available show that, far from being derived from the eastern Mediterranean, the megalithic complex preceded in its inception the major monuments of the Ancient Near East.

Part III sets out Glyn Daniel's influence in many different ways in awakening and stimulating public interest in archaeology: as an editor, particularly of the Ancient Peoples and Places series, as an "anchor man" of the television programme Animal, Vegetable, Mineral with Sir Mortimer Wheeler and later of the Buried Treasure series with Paul Johnston. His influence could not have been greater than through his editorship of Antiquity, so ably helped by his wife Ruth as production manager. This is and will remain, it is hoped, one of the leading archaeological journals.

These essays also bring out, especially in Part IV, what is perhaps Professor Daniel's most significant contribution, namely his great success as a teacher. Many of the essays are written by his former students and the high praise and affection with which they all speak of him bears ample witness to the wit and erudition with which he enlivened his lectures and to his natural ability to produce enthusiastic and professional archaeologists who have remained his friends.

Besides being a valuable supplement to A Short History of Archaeology, this volume is full of entertaining asides about archaeology and publishing, amateurs in archaeology and the public image of the archaeologist. It also contains interesting information about Glyn himself, his many achievements and his progresses through the menus gastronomiques of Brittany and the wine country of the Dordogne in his pursuit of archaeology.

Both books show very clearly how the discipline of archaeology is a product of Western European civilization. But the focus has now shifted to the Third World and other countries since it is here that we are learning what it was that made us human. It is here also that archaeology has a greater role to play than in the Western world since, for many nations, it is the most important source of knowledge of their past. Even though this may be regarded as only small beer and lentils, the record is as good as or surpasses that which has gone before.

J. Desmond Clark is a Professor in the Department of Anthropology at the University of California, Berkeley. 